Article

\title{
Impact of Storage Conditions on the Methanogenic Activity of Anaerobic Digestion Inocula
}

\author{
Sergi Astals ${ }^{1,2, *(\mathbb{D})}$, Konrad Koch ${ }^{3}\left(\mathbb{D}\right.$, Sören Weinrich ${ }^{4}$, Sasha D. Hafner ${ }^{5}\left(\mathbb{D}\right.$, Stephan Tait ${ }^{2}$ \\ and Miriam Peces ${ }^{2,6, *}$ \\ 1 Department of Chemical Engineering and Analytical Chemistry, University of Barcelona, \\ 08028 Barcelona, Spain \\ 2 Advanced Water Management Centre, The University of Queensland, Brisbane, QLD 4072, Australia; \\ s.tait@awmc.uq.edu.au \\ 3 Chair of Urban Water Systems Engineering, Technical University of Munich, Am Coulombwall 3, \\ 85748 Garching, Germany; k.koch@tum.de \\ 4 Biochemical Conversion Department, Deutsches Biomasseforschungszentrum Gemeinnützige GmbH, \\ Torgauer Straße 116, 04347 Leipzig, Germany; soeren.weinrich@dbfz.de \\ 5 Hafner Consulting LLC, Reston, VA 20191, USA; sasha@hafnerconsulting.com \\ 6 Department of Chemistry and Bioscience, Centre for Microbial Communities, Aalborg University, \\ 9220 Aalborg, Denmark \\ * Correspondence: sastals@ub.edu (S.A.); mpg@bio.aau.dk (M.P.)
}

Received: 5 April 2020; Accepted: 4 May 2020; Published: 7 May 2020

\begin{abstract}
The impact of storage temperature $\left(4,22\right.$ and $\left.37^{\circ} \mathrm{C}\right)$ and storage time $(7,14$ and 21 days) on anaerobic digestion inocula was investigated through specific methanogenic activity assays. Experimental results showed that methanogenic activity decreased over time with storage, regardless of storage temperature. However, the rate at which the methanogenic activity decreased was two and five times slower at $4{ }^{\circ} \mathrm{C}$ than at 22 and $37{ }^{\circ} \mathrm{C}$, respectively. The inoculum stored at $4{ }^{\circ} \mathrm{C}$ and room temperature $\left(22^{\circ} \mathrm{C}\right)$ maintained methanogenic activity close to that of fresh inoculum for 14 days $\left(<10 \%\right.$ difference). However, a storage temperature of $4{ }^{\circ} \mathrm{C}$ is preferred because of the slower decrease in activity with lengthier storage time. From this research, it was concluded that inoculum storage time should generally be kept to a minimum, but that storage at $4{ }^{\circ} \mathrm{C}$ could help maintain methanogenic activity for longer.
\end{abstract}

Keywords: anaerobic digestion; biogas; inoculum; sample storage; methanogenesis; specific methanogenic activity (SMA); biochemical methane potential (BMP) test

\section{Introduction}

Anaerobic digestion is a technology used for the treatment of organic-rich waste streams, which produces biogas as a renewable energy source. The growing importance of anaerobic digestion application and research has required technicians, practitioners and academics to increasingly conduct: (1) metabolic assays to assess the activity of a digester's microbial community (e.g., specific methanogenic activity (SMA)) [1,2]; (2) biochemical methane potential (BMP) tests to quantify the methane yield of a digester's feedstock [3-6]; (3) residual methane potential tests to determine the methane potential of a digester's effluent and thus the efficiency of the anaerobic digestion process $[7,8]$; and (4) anaerobic toxicity assays (ATA) to determine the resilience of a digester's microbial community towards an inhibitor $[9,10]$. These assays provide crucial insights to guide successful anaerobic digestion operations. This will be especially important as the range of feedstocks treated through anaerobic digestion increases, digester's operational conditions are intensified to maximise the use of 
existing infrastructure, and the increasingly widespread adoption of co-digestion to divert residues away from landfill and boosts local renewable energy supply.

To conduct these assays, it is generally preferred to use fresh inoculum $[3,4,11,12]$. However, in some situations, fresh inoculum is not readily accessible. For example, for full-scale applications, the inoculum (digestate) may need to be shipped from the full-scale anaerobic digestion plant to the laboratory. For lab-scale applications, the inoculum may need to be collected over a certain period of time to accumulate the amount of inoculum needed to conduct the experiment or stored until the laboratory infrastructure becomes available. This introduces uncertainty regarding the potential impacts that different transport and storage conditions have on inoculum activity and thus on the efficacy of the inoculum when used in the assay.

Table 1 summarises publications studying the impact of storage temperature and storage time on inoculum capacity. Storing the inoculum at $4{ }^{\circ} \mathrm{C}$ and room temperature $\left(20-25^{\circ} \mathrm{C}\right)$ have been reported as the preferred options when compared to freezing $\left(-20^{\circ} \mathrm{C}\right)$ and freeze-drying $[13,14]$. For example, Castro et al. [13] reported a $40 \%$ reduction in methanogenic activity at either $4{ }^{\circ} \mathrm{C}$ or room temperature after 2 months of storage. Hagen et al. [14] concluded that an inoculum could be stored for up to 1 month at $4{ }^{\circ} \mathrm{C}$ or room temperature without a major impact on BMP test results. However, BMP tests carried out with the inoculum stored for a longer time (2, 6 and 11 months) showed a significantly lower methane yield and degradation rate [14]. For BMP tests, inoculum storage at the test temperature (30-38 ${ }^{\circ} \mathrm{C}$ for mesophilic conditions, $50-55{ }^{\circ} \mathrm{C}$ for thermophilic conditions) for a few days (1-7 days) is a common practice to reduce the residual background methane production [3,15-17]. However, Wang et al. [18], Koch et al. [12] and Elbeshbishy et al. [11] have shown that storing an inoculum at mesophilic conditions for 5, 14 and 35 days, respectively, worsened BMP test results compared to using fresh inoculum. Wang et al. [18] and Koch et al. [12] also studied the difference between storing the inoculum at $4{ }^{\circ} \mathrm{C}$ and at $35^{\circ} \mathrm{C}$, both concluding that storage at $4{ }^{\circ} \mathrm{C}$ had a slightly lower impact on BMP test results.

Most of the studies in the literature analysed the impact of storage time and temperature through BMP tests $[11,12,14,18,19]$ (Table 1), likely because BMP tests are the most popular assay in the anaerobic digestion field. However, BMP tests can be less sensitive than metabolic assays (e.g., SMA) to changes in inoculum activity, since BMP tests comprise the entire degradation process while metabolic assays directly target a specific biological step of the overall anaerobic digestion process [1,9]. It should be noted that BMP tests are designed to determine the methane yield of a substrate, while metabolic assays are designed to determine the degradation kinetics. Therefore, metabolic assays stand as a more conservative approach to assess the impact of storage conditions on inoculum activity. In metabolic activity and toxicity assays, methanogenic activity is typically used over other steps (i.e., hydrolysis, acidogenesis, acetogenesis) because it is generally acknowledged to be the most sensitive step of the anaerobic digestion process $[1,10,20,21]$. Therefore, storage conditions that do not affect SMA are not expected to have any impact on BMP test results. To the best of our knowledge, Castro et al. [13] is the only study that tested the impact of inoculum storage through SMA tests. Nonetheless, the long storage times tested by Castro et al. [13] ( 2 and 5 months) did not provide information on how long the inoculum could be stored for at $4{ }^{\circ} \mathrm{C}$ and room temperature before losing a significant amount of its original activity, nor the relationship between storage temperature and loss of activity.

In the present study, the impact of storage temperature $\left(4,22\right.$ and $\left.37^{\circ} \mathrm{C}\right)$ and storage time $(7,14$ and 21 days) on inoculum methanogenic activity was investigated. The goal was to determine the best storage conditions as well as for how long an inoculum could be stored at such conditions without significant losses in methanogenic activity. 
Table 1. Summary of publications studying the impact of storage conditions on inoculum capacity.

\begin{tabular}{|c|c|c|c|c|c|c|}
\hline Storage Temperature & Storage Time & Test & Inoculum & Substrate & Observations & Ref. \\
\hline $\begin{array}{l}-20^{\circ} \mathrm{C} \text {, freeze-drying, } 4^{\circ} \mathrm{C} \\
\text { and room temperature }\end{array}$ & 2 and 5 months & SMA & $\begin{array}{c}\text { Psychrophilic } \\
\text { anaerobic lagoon }{ }^{1}\end{array}$ & Glucose Acetate & $\begin{array}{l}\text { - Storage decreased the inoculum activity regardless of the storage } \\
\text { temperature and time } \\
\text { - Storage at } 4^{\circ} \mathrm{C} \text { and room temperature affected the fermentation } \\
\text { (glucose) and the methanogenic (acetate) activity less than freezing } \\
\text { and freeze-drying } \\
\text { - After } 2 \text { months storage at } 4^{\circ} \mathrm{C} \text { and room temperature, the inoculum lost } \\
\text { ca. } 20 \% \text { of its fermentation activity and ca. } 40 \% \text { of its } \\
\text { methanogenic activity }\end{array}$ & [13] \\
\hline $37^{\circ} \mathrm{C}$ & 35 days & BMP & Mesophilic DSS ${ }^{2}$ & Primary sludge & $\begin{array}{l}\text { - The stored inoculum showed a longer lag-phase than the fresh inoculum } \\
\text { - The stored inoculum showed a slightly lower } B_{0} \text { and degradation rate }\end{array}$ & [11] \\
\hline Room temperature & 2 and 4 months & BMP & $\begin{array}{l}\text { Thermophilic } \\
\text { OFMSW digester }\end{array}$ & $\begin{array}{l}\text { OFMSW Non-fat dry } \\
\text { milk }\end{array}$ & $\begin{array}{l}\text { - The stored inoculum showed a noticeably lower } \mathrm{B}_{0} \text { and degradation rate } \\
\text { for both substrates } \\
\text { - The inoculum stored for } 2 \text { months displayed a longer lag-phase } \\
\text { - The inoculum stored for } 4 \text { months displayed a polyauxic behaviour }{ }^{4}\end{array}$ & [19] \\
\hline $\begin{array}{l}-20^{\circ} \mathrm{C}, 4^{\circ} \mathrm{C} \text { and room } \\
\text { temperature }\end{array}$ & $\begin{array}{l}1 \text { week; } 1,2,6 \text { and } \\
11 \text { months }\end{array}$ & BMP & $\begin{array}{c}\text { Mesophilic } \\
\text { co-digester (OFMSW } \\
\text { and cow manure) }{ }^{5}\end{array}$ & Cellulose & $\begin{array}{l}\text { - } 1 \text { week and } 1 \text { month storage at } 4^{\circ} \mathrm{C} \text { and room temperature did not have } \\
\text { a major impact } \\
\text { - Freezing the inoculum for } 1 \text { week and } 1 \text { month did not impact } \mathrm{B}_{0} \text { but } \\
\text { decreased the degradation rate } \\
\text { - Storing the inoculum for } 2 \text { months or longer significantly decreased both } \\
\mathrm{B}_{0} \text { and the degradation rate for the three storage temperatures }\end{array}$ & [14] \\
\hline $4^{\circ} \mathrm{C}$ and $37^{\circ} \mathrm{C}$ & 5 days & BMP & Mesophilic DSS & $\begin{array}{l}\text { Cellulose Wheat } \\
\text { straw }\end{array}$ & $\begin{array}{l}\text { - For cellulose, the inocula stored at } 4 \text { and } 37^{\circ} \mathrm{C} \text { showed slightly lower } \mathrm{B}_{0} \\
\text { than the fresh inoculum } \\
\text { - For wheat straw, inoculum storage at } 4^{\circ} \mathrm{C} \text { did not affect } \mathrm{B}_{0} \text {, while } \\
\text { storing the inoculum at } 37^{\circ} \mathrm{C} \text { slightly decreased } \mathrm{B}_{0}\end{array}$ & [18] \\
\hline $4^{\circ} \mathrm{C}$ and $38^{\circ} \mathrm{C}$ & 2 weeks & BMP & Mesophilic DSS & Pelleted dog food & $\begin{array}{l}\text { - The stored inoculum showed a slower degradation rate than the } \\
\text { fresh inoculum } \\
\text { - The inoculum stored at } 4^{\circ} \mathrm{C} \text { reached the same } \mathrm{B}_{0} \text { as the fresh inoculum, } \\
\text { while the one stored at } 38^{\circ} \mathrm{C} \text { reached a slightly lower } \mathrm{B}_{0}\end{array}$ & [12] \\
\hline
\end{tabular}

Abbreviations: $\mathrm{B}_{0}$ stands for the ultimate methane yield $\left(\mathrm{mLCH}_{4} \cdot \mathrm{gVS}^{-1}\right)$; BMP stands for biochemical methane potential; DSS stands for digested sewage sludge; OFMSW stands for organic fraction of the municipal solid waste; SMA stands for specific methanogenic activity. ${ }^{1}$ Before storage the inoculum was washed and re-suspended with a mineral and vitamin solution and pre-incubated at $30^{\circ} \mathrm{C}$ until methane production ceased. ${ }^{2}$ Before storage the inoculum was pre-incubated at $37^{\circ} \mathrm{C}$ until the daily methane production was lower than $1 \%$ of the cumulative methane. ${ }^{3}$ Before storage the inoculum was incubated for 10 days at $55{ }^{\circ} \mathrm{C} .{ }^{4}$ Plot displaying a long lag-phase and a multi-phase growth. ${ }^{5}$ Before storage the inoculum was incubated for 10 days at $37^{\circ} \mathrm{C}$, sieved and diluted. 


\section{Materials and Methods}

\subsection{Analytical Methods}

Analyses of the total fraction were performed directly on the raw samples. For analyses of the soluble fraction, the samples were centrifuged at $2500 \times g$ for $5 \mathrm{~min}$ and the supernatant was filtered through a $0.45 \mu \mathrm{m}$ PES Millipore ${ }^{\circledR}$ filter. Total solids (TS) and volatile solids (VS) were measured according to Standard Methods 2540G [22]. Total chemical oxygen demand (tCOD) and soluble chemical oxygen demand (sCOD) were measured using Merck COD Spectroquant ${ }^{\circledR}$ test kits and a Move 100 colorimeter (Merck, Germany). The pH was measured with a TPS-121210 micro pH sensor. Alkalinity was determined following the Standard Methods 2320B procedure [22] with a Mettler Toledo automatic titrator (Titrator Excellence T5) using a $0.1 \mathrm{M} \mathrm{HCl}$ solution and a $\mathrm{pH}$ end point of 4.3. Volatile fatty acids (acetic, propionic, butyric and valeric acid) were analysed with an Agilent 7890A gas chromatograph equipped with an Agilent DB-FFAP capillary column and a flame ionisation detector. Total ammonia nitrogen (TAN) and total Kjeldahl nitrogen (TKN) were determined by a Lachat QuickChem 8500 flow injection analyser following the manufacturer's protocol. Biogas composition $\left(\mathrm{CH}_{4}, \mathrm{CO}_{2}, \mathrm{H}_{2}\right.$ and $\left.\mathrm{N}_{2}\right)$ was determined using a Shimadzu GC-2014 equipped with a HAYESEP Q 80/100 packed column and a thermal conductivity detector.

\subsection{Chemical Reagents and Inoculum Source}

Analytical reagent grade anhydrous sodium acetate (Chem-Supply, Australia) was used as a substrate in the specific methanogenic activity (SMA) assays. Two inocula were used in this study: digested pig manure (DPM) and digested sewage sludge (DSS). DPM was collected from a $4 \mathrm{~L}$ lab-scale continuous stirred tank reactor (CSTR) treating pig manure at mesophilic conditions $\left(37 \pm 1^{\circ} \mathrm{C}\right)$. The digester was fed with diluted pig manure $\left(\sim 10 \mathrm{gVS} \cdot \mathrm{L}^{-1}\right)$ collected from a specialised breeder piggery near Grantham (Queensland, Australia). The digester was operated at a hydraulic retention time (HRT) of 20-22 days and an organic loading rate (OLR) of $0.5-0.6 \mathrm{gVS} \cdot \mathrm{L}^{-1} \cdot \mathrm{d}^{-1}$. DSS was collected from a full-scale mesophilic digester $\left(35 \pm 2{ }^{\circ} \mathrm{C}\right)$ that treats mixed sewage sludge in a conventional municipal wastewater treatment plant (WWTP) in South East Queensland (Australia). The $5500 \mathrm{~m}^{3}$ digester operates at an HRT of 23-25 days and an OLR of $0.8-1.0 \mathrm{gVS} \cdot \mathrm{L}^{-1} \cdot \mathrm{d}^{-1}$. Two batches of DSS from the same digester were used in this study. Table 2 displays the chemical composition of the three inocula.

Table 2. Chemical composition of the raw inocula.

\begin{tabular}{ccccc}
\hline Parameter & Units & DPM & $\begin{array}{c}\text { DSS } \\
\text { (Batch 1) }\end{array}$ & $\begin{array}{c}\text { DSS } \\
\text { (Batch 2) }\end{array}$ \\
\hline TS & ${\mathrm{g} \mathrm{TS} \cdot \mathrm{kg}^{-1}}_{\mathrm{GS}}^{\mathrm{g} \mathrm{VS}_{\mathrm{kg}}-1}$ & 6.5 & 27.0 & 28.6 \\
$\mathrm{tCOD}$ & ${\mathrm{g} \mathrm{COD} \cdot \mathrm{kg}^{-1}}_{\mathrm{g} \mathrm{COD} \cdot \mathrm{kg}^{-1}}$ & 6.2 & 18.8 & 20.5 \\
$\mathrm{sCOD}$ & - & 0.3 & 27.4 & 31.4 \\
$\mathrm{pH}$ & 7.5 & 0.1 & 0.1 \\
Alkalinity & $\mathrm{g} \mathrm{CaCO}_{3} \cdot \mathrm{L}^{-1}$ & 1.4 & 7.5 & 7.4 \\
VFA & $\mathrm{mg} \mathrm{VFA} \cdot \mathrm{L}^{-1}$ & 5 & $\mathrm{n} . \mathrm{d}$. & 5.2 \\
TAN & $\mathrm{mg} \mathrm{N} \cdot \mathrm{L}^{-1}$ & 177 & 1105 & 23 \\
Phosphate & $\mathrm{mg} \mathrm{P} \cdot \mathrm{L}^{-1}$ & 82 & 183 & 1246 \\
\hline
\end{tabular}

n.d. stands for not determined.

\subsection{Specific Methanogenic Activity (SMA) Test Set-up}

SMA tests were performed following the method described by Soto et al. [1] and Astals et al. [10] to ensure zero-order kinetics. Specifically, serum bottles $(115 \mathrm{~mL})$ were prepared containing: (1) $80 \mathrm{~mL}$ of inoculum and (2) the amount of sodium acetate solution (stock solution $200 \mathrm{~g}_{\text {acetate }} \cdot \mathrm{L}^{-1}$ ) needed to achieve an inoculum-to-acetate ratio of 5 (VS basis). The DPM inoculum was not diluted due 
to its low VS concentration (4.2 gVS. $\mathrm{L}^{-1}$ ), while the DSS inoculum was diluted to $10 \mathrm{gVS} \cdot \mathrm{L}^{-1}$ with deionised water to prevent mass-transfer limitations as suggested by Astals et al. [10]. The headspace of each serum bottle was flushed for $30 \mathrm{~s}\left(4 \mathrm{~L} \cdot \mathrm{min}^{-1}\right)$ with $99.99 \% \mathrm{~N}_{2}$ before sealing the bottle with a T-shape butyl rubber stopper and aluminium crimp seal. The gas line was not submerged during flushing to prevent $\mathrm{CO}_{2}$ stripping and associated $\mathrm{pH}$ changes. Subsequently, the serum bottles were placed in a temperature-controlled incubator at $37 \pm 1{ }^{\circ} \mathrm{C}$. The bottles were mixed by manual swirling before and after each sampling event. The methanogenic rate was determined by measuring methane production, calculated from the pressure increase and methane composition of the headspace at each sampling event (ca. 5, 10, 24, 30 and $35 \mathrm{~h}$ after the beginning of the experiment). The headspace pressure was measured using a manometer at the start of each sampling event, while the methane composition was determined using a gas chromatograph. Methane production is reported at standard conditions (i.e., $0^{\circ} \mathrm{C}, 1 \mathrm{~atm}$, dry) in COD equivalents ( $350 \mathrm{~mL} \mathrm{CH}_{4}$ equals $1 \mathrm{~g} \mathrm{COD}$ ) (calculations are described in Hafner et al. [23]). Methane production calculations were cross-validated with the OBA web application [24]. Blank tests (inoculum-only) were carried out for all storage conditions to correct for inoculum background methane production. All conditions were tested in triplicate.

Table 3 summarises the test conditions of the three sets of experiments carried out in this study. The experimental conditions of each experiment were as follows:

Table 3. Experimental conditions tested for each experiment.

\begin{tabular}{|c|c|c|c|}
\hline Experiment & Inoculum & Storage Temperature & Storage Time \\
\hline 1 & $\mathrm{DPM}$ & $\begin{array}{c}\text { Non-stored (control) } \\
\text { Refrigerator }\left(4^{\circ} \mathrm{C}\right) \\
\text { Refrigerator }\left(4^{\circ} \mathrm{C}\right)+1 \text { day at } 37^{\circ} \mathrm{C} \\
\text { Incubator at } 37^{\circ} \mathrm{C}\end{array}$ & 8 days $^{2}$ \\
\hline 2 & DSS & $\begin{array}{c}\text { Non-stored (control) }{ }^{1} \\
\text { Refrigerator }\left(4^{\circ} \mathrm{C}\right) \\
\text { Refrigerator }\left(4^{\circ} \mathrm{C}\right)+1 \text { day at } 37^{\circ} \mathrm{C} \\
\text { Incubator at } 37^{\circ} \mathrm{C}\end{array}$ & 7 days \\
\hline 3 & DSS & $\begin{array}{c}\text { Non-stored (control) } \\
\text { Refrigerator }\left(4^{\circ} \mathrm{C}\right) \\
\text { Room temperature }\left(22{ }^{\circ} \mathrm{C}\right) \\
\text { Incubator at } 37^{\circ} \mathrm{C}\end{array}$ & 7,14 and 21 days \\
\hline
\end{tabular}

\subsubsection{Experiment 1: Impact of Storage Temperature on DPM Inoculum}

Experiment 1 aimed to determine the impact of storage temperature on the inoculum SMA. Three different storage conditions were tested: (1) refrigerator $\left(4^{\circ} \mathrm{C}\right)$ for 8 days, (2) incubator at $37^{\circ} \mathrm{C}$ for 8 days, and (3) refrigerator $\left(4^{\circ} \mathrm{C}\right)$ for 7 days followed by a 1 -day pre-incubation at $37^{\circ} \mathrm{C}$. The DPM inoculum was collected from the lab-scale digester over 7 days because the daily effluent removal from the lab-scale digester was $200 \mathrm{~mL}$. Each day, the effluent was split into three aliquots and stored in $1 \mathrm{~L}$ plastic bottles. The bottles were stored tightly capped. Tests were carried out 8 days after starting the inoculum collection. The storage conditions were compared to a control of fresh inoculum (non-stored inoculum), which was obtained by removing $600 \mathrm{~mL}$ from the digester content on the test day.

\subsubsection{Experiment 2: Impact of Storage Temperature on DSS Inoculum}

Experiment 2 also aimed to determine the impact of storage temperature on the inoculum SMA. The tested storage conditions were the same as in Experiment 1: (1) refrigerator $\left(4^{\circ} \mathrm{C}\right)$ for 7 days, (2) incubator at $37^{\circ} \mathrm{C}$ for 7 days, and (3) refrigerator $\left(4^{\circ} \mathrm{C}\right)$ for 6 days followed by a 1-day pre-incubation at $37^{\circ} \mathrm{C}$. In Experiment 2, the entire inoculum was collected in a single batch from the full-scale digester. 
The fresh inoculum (control) test was carried out $14 \mathrm{~h}$ after its collection. During this time the inoculum was stored in a loosely capped bottle at $37^{\circ} \mathrm{C}$ since this was the original digester temperature.

\subsubsection{Experiment 3: Impact of Storage Temperature and Storage Time on DSS Inoculum}

Experiment 3 aimed to determine the impact of storage temperature and storage time on the inoculum SMA. The storage conditions were: (1) refrigerator $\left(4^{\circ} \mathrm{C}\right),(2)$ laboratory at a room temperature of $22 \pm 2{ }^{\circ} \mathrm{C}$ (the laboratory was temperature controlled at $22^{\circ} \mathrm{C}$ ), and (3) incubator at $37^{\circ} \mathrm{C}$. For each storage temperature, the SMA was tested after 7, 14 and 21 days of storage. A fresh control was included as in the other experiments, which was carried out $16 \mathrm{~h}$ after inoculum collection. During this time, the inoculum was stored in a loosely capped bottle at $37^{\circ} \mathrm{C}$, as in Experiment 2 .

\subsection{Data Analysis}

Monod kinetics were used to describe the SMA [1]. Assuming negligible biomass growth and an excess of substrate, Monod kinetics can be simplified to a zero-order kinetic model [2]. The SMA ( $\mathrm{g} \mathrm{COD} \cdot \mathrm{g} \mathrm{VS}^{-1} \cdot \mathrm{day}^{-1}$ ) was calculated as the slope of a linear regression applied to the cumulative methane production (g COD.g VS ${ }^{-1}, y$-axis) and time (day, $x$-axis) for the subset of data over which the rate of methane production was approximately constant (zero-order). A linear regression was carried out using the Analysis Toolpak in Microsoft Excel 2019. Variability was summarised as 95\% confidence intervals around a mean value for the three samples using a two-tailed student $t$-distribution with two degrees of freedom.

\section{Results}

\subsection{Impact of Storage Temperature on SMA}

Table 4 shows the impact of the storage temperature on the SMA of DPM and DSS (Experiment 1 and Experiment 2, respectively). The SMA of the two fresh inocula were, coincidentally, virtually identical and in agreement with values reported in previous publications $[2,10,25,26]$. For the DPM inoculum, there were no clear differences between the SMA of fresh inoculum and the SMA of inoculum stored under different temperature conditions (maximum of $3 \%$ difference, $\mathrm{P}>0.125$ ). Regarding DSS, no significant difference was found between the fresh inoculum and the inoculum stored at $4{ }^{\circ} \mathrm{C}$ for 7 days, with or without a 1-day pre-incubation at $37^{\circ} \mathrm{C}$ (maximum of $5 \%$ difference, $\mathrm{P}>0.089$ ). However, the inoculum stored at $37^{\circ} \mathrm{C}$ lost $20 \%$ of its original methanogenic activity after 7 days of storage $(\mathrm{P}=0.022)$.

Table 4. Impact of storage temperature on DPM and DSS specific methanogenic activity $\left(\mathrm{g} \mathrm{COD} \cdot \mathrm{g} \mathrm{VS}^{-1} \cdot \mathrm{d}^{-1}\right)$. Results are expressed as average $\pm 95 \%$ confidence interval $(\mathrm{n}=3)$.

\begin{tabular}{cccccc}
\hline Experiment & Inoculum & $\begin{array}{c}\text { Non-Stored } \\
\text { (Control) }\end{array}$ & $\begin{array}{c}\text { Refrigerator } \\
\left(\mathbf{4}{ }^{\circ} \mathbf{C}\right)\end{array}$ & $\begin{array}{c}\text { Refrigerator }\left(\mathbf{4}^{\circ} \mathbf{C}\right) \\
\mathbf{+ 1} \text { Day at } \mathbf{3 7}{ }^{\circ} \mathbf{C}\end{array}$ & $\begin{array}{c}\text { Incubator } \\
\left(\mathbf{3 7}{ }^{\circ} \mathbf{C}\right)\end{array}$ \\
\hline 1 & DPM & $0.127 \pm 0.005$ & $0.128 \pm 0.005$ & $0.123 \pm 0.003$ & $0.126 \pm 0.006$ \\
2 & DSS & $0.128 \pm 0.004$ & $0.133 \pm 0.003$ & $0.121 \pm 0.004$ & $0.103 \pm 0.005$ \\
\hline
\end{tabular}

The results from Experiment 1 and Experiment 2 indicate that storing the inoculum at $37^{\circ} \mathrm{C}$ can have an impact on inoculum activity. However, the decrease in activity was presumably related to the inoculum storage time, which can be hypothesised by comparing the response between the DPM and DSS inocula. Specifically, DPM had an average storage time of 4 days (being collected over 8 consecutive days) while DSS was stored for 7 days. Experiment 3 studied in detail the impact of storage time on the inoculum SMA (see Section 3.2). On the other hand, Experiment 1 and Experiment 2 showed that inoculum storage at $4{ }^{\circ} \mathrm{C}$ maintained the methanogenic activity for both inocula. Finally, these experiments showed that a 1-day pre-incubation at $37^{\circ} \mathrm{C}$ to acclimatise the inoculum to the test temperature before the start of the assay did not affect the test results and hence is not needed. 


\subsection{Impact of Storage Temperature and Storage Time on SMA}

Figure 1 shows the impact of storage temperature $\left(4,22\right.$ and $\left.37^{\circ} \mathrm{C}\right)$ and storage time $(7,14$ and 21 days) on DSS methanogenic activity (Experiment 3). The results obtained after 7 days of storage in Experiment 3 are in agreement with the results obtained in Experiment 2, since DSS inoculum storage at $4{ }^{\circ} \mathrm{C}$ had no significant impact on the inoculum SMA $(\mathrm{P}=0.460)$, and inoculum storage at $37^{\circ} \mathrm{C}$ significantly decreased the inoculum SMA $(\mathrm{P}<0.001)$. However, in Experiment 3 , the decrease in the inoculum SMA stored at $37^{\circ} \mathrm{C}$ was more acute than was observed in Experiment 2 (i.e., $37 \%$ activity loss after 7 days instead of $20 \%)$. DSS storage at room temperature $\left(22^{\circ} \mathrm{C}\right)$ for 7 days had no significant impact on the inoculum SMA when compared to the fresh inoculum $(\mathrm{P}=0.077)$. After 21 days of storage, the DSS inoculum had lost $11 \%, 21 \%$ and $89 \%$ of its original activity when stored at 4,22 , and $37^{\circ} \mathrm{C}$, respectively (Table S1 in Supplementary Materials).

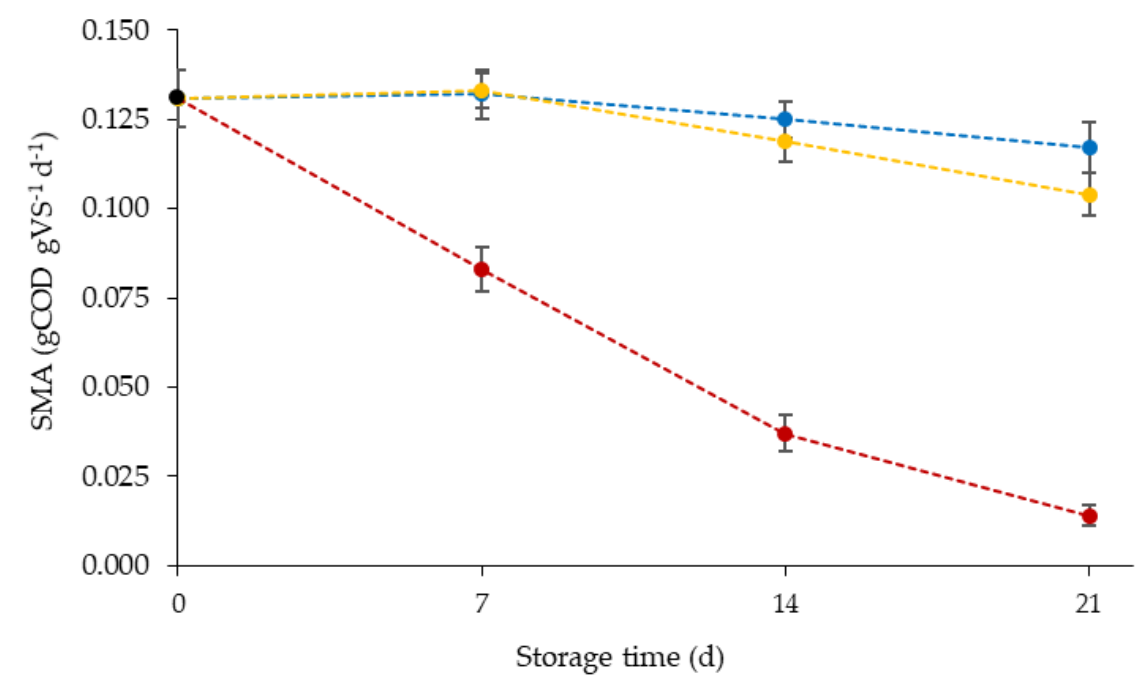

Figure 1. Impact of storage temperature and storage time on DSS specific methanogenic activity at $4{ }^{\circ} \mathrm{C}$ (blue), $22^{\circ} \mathrm{C}$ (yellow) and $37^{\circ} \mathrm{C}$ (red). Results are expressed as average $\pm 95 \%$ confidence interval $(\mathrm{n}=3)$.

The loss of methanogenic activity during storage approximately followed a linear trend over time for the inoculum stored at $37^{\circ} \mathrm{C}$, and also for the inoculum stored at $4{ }^{\circ} \mathrm{C}$ and $22{ }^{\circ} \mathrm{C}$, excluding the first 7 days when the SMA remained relatively constant $\left(R^{2}>0.97\right)$. Regression analysis showed that the rate at which the inoculum lost its activity was significantly different for each storage temperature $(\mathrm{P}<0.001)$. Specifically, the inoculum stored at $4{ }^{\circ} \mathrm{C}, 22{ }^{\circ} \mathrm{C}$ and $37{ }^{\circ} \mathrm{C}$ lost $0.0011,0.0022$ and $0.00057 \mathrm{~g} \mathrm{COD} \cdot \mathrm{g} \mathrm{VS}^{-1} \cdot \mathrm{d}^{-1}$ per day, respectively. Relative to the fresh inoculum activity, the SMA losses were $0.80 \pm 0.19 \%, 1.6 \pm 0.2 \%$ and $4.3 \pm 0.5 \%$ per day for the inoculum stored at $4{ }^{\circ} \mathrm{C}, 22{ }^{\circ} \mathrm{C}$ and $37^{\circ} \mathrm{C}$, respectively (see Figure S1 in the Supplementary Materials). These results indicate that: (1) the loss of methanogenic activity is progressive over time, and (2) the rate of activity loss increases with an increase in the storage temperature. The slowest SMA loss rate makes $4{ }^{\circ} \mathrm{C}$ the preferred storage temperature. In contrast, the fastest SMA loss rate at $37^{\circ} \mathrm{C}$ strongly discourages the use of this temperature for inoculum storage. Regardless of the storage temperature, the progressive loss of activity indicates that storage time should be as short as possible.

\section{Discussion}

\subsection{Impact of Storage Temperature on Inoculum Activity}

The experimental results of this study showed that storing the inoculum at $4{ }^{\circ} \mathrm{C}$ is the preferred option to maintain the inoculum methanogenic activity for both short-term and long-term storage. 
This conclusion is in agreement with the general trend observed in previous publications (Table 1), where inoculum storage at $4{ }^{\circ} \mathrm{C}$ provided better results than other conditions, including freezing $\left(-20^{\circ} \mathrm{C}\right)$, freeze-drying, room temperature $\left(20-22{ }^{\circ} \mathrm{C}\right)$, and mesophilic temperatures $\left(35-38{ }^{\circ} \mathrm{C}\right)$. Results from Experiment 1 and Experiment 2 also showed that a 1-day pre-incubation at $37^{\circ} \mathrm{C}$ (after storage at $4{ }^{\circ} \mathrm{C}$ ) to acclimatise the inoculum to the test temperature did not affect the inoculum methanogenic activity. Therefore, the inoculum can be stored in a refrigerator at $4{ }^{\circ} \mathrm{C}$ until the beginning of the experimental set-up without pre-incubation. It should be noted that the methane produced between the beginning of the experiment and the first sampling event (ca. 5-6 h) was not used for the SMA calculations, since SMA tests can characteristically display a lag-phase. Therefore, the inoculum had enough time to reach the SMA at the target temperature before the relevant sampling events had occurred. Additionally, the amount of time that the inoculum was out of the refrigerator during the experiment set-up (ca. $30 \mathrm{~min}$ ) and, for DSS, the dilution of the inoculum with deionised water at ambient temperature, would have increased the inoculum temperature to an extent before the test bottles were placed in the $37^{\circ} \mathrm{C}$ incubator.

Storing the inoculum at room temperature was the second-best tested storage condition. In Experiment 3, the inoculum stored at $22{ }^{\circ} \mathrm{C}$ kept an SMA close to the original for up to 7 days, and afterwards, the rate of activity loss was relatively low $(1.6 \pm 0.2 \%$ per day). These results are similar to observations reported by Hagen et al. [14], who did not find any significant difference between storing a co-digestion inoculum (food waste and cattle manure) for 1 week or 1 month, at $4{ }^{\circ} \mathrm{C}$ or at room temperature (the specific room temperature was not reported). However, Hagen et al. [14] assessed the impact of inoculum storage through biochemical methane potential (BMP) tests using cellulose as a substrate, which is less sensitive than the SMA test to small changes in microbial metabolic activity. The SMA test response is also likely to be less affected by microbial growth and microbial acclimation due to the shorter duration of the experiment. Additionally, it is widely accepted that cellulose anaerobic degradation is controlled by the hydrolysis step [27,28]. According to Castro et al. [13], for inocula stored at $4{ }^{\circ} \mathrm{C}$ and room temperature, the loss of activity is lower for hydrolytic-fermentative bacteria than for methanogenic archaea.

Storing the inoculum at $37^{\circ} \mathrm{C}$ provided the worst results among the tested storage conditions and therefore it is not recommended. Specifically, the DSS inoculum lost $20 \%$ and $37 \%$ of its methanogenic activity after 7 days of storage in Experiment 2 and Experiment 3, respectively. However, there was no significant loss of methanogenic activity for the DPM inoculum after 8 days at $37^{\circ} \mathrm{C}$ compared to the fresh inoculum and compared to the DPM inoculum stored at $4{ }^{\circ} \mathrm{C}$. However, DPM was collected from a lab-scale digester over a period of time, so that the average storage time of this inoculum was about 4 days, whereas the DSS inoculum was collected in a single batch from a full-scale digester. These results indicate that the loss of activity is progressive over time and that inoculum degassing prior to BMP testing is only advisable for a very short time period.

\subsection{Impact of Storage Time on Inoculum Activity}

Experiment 3 showed that the methanogenic activity of the inoculum decreased over time regardless of the storage conditions (Figure 1). However, the rate at which the inoculum activity was lost depended on the storage temperature. The inocula stored at $4{ }^{\circ} \mathrm{C}$ and room temperature maintained methanogenic activity close to the original for about 7 days. Subsequently, the loss of activity followed a linear trend over time, losing $0.8 \%$ and $1.6 \%$ of methanogenic activity per day (see Figure S1 in the Supplementary Materials). The loss of methanogenic activity over time was more acute for the inoculum stored at $37^{\circ} \mathrm{C}$. Specifically, the loss of methanogenic activity was approximately three and five times faster at $37^{\circ} \mathrm{C}$ than at 22 and $4{ }^{\circ} \mathrm{C}$, respectively.

The progressive loss of inoculum activity over time with storage and the more detrimental impact of storage at $37^{\circ} \mathrm{C}$ compared to storage at $4{ }^{\circ} \mathrm{C}$ or room temperature $\left(22^{\circ} \mathrm{C}\right)$ is in agreement with the general trend observed in previous publications (Table 1). This could be due to a higher substrate uptake rate and decay rate of anaerobic microorganisms at $37^{\circ} \mathrm{C}$ than at $22^{\circ} \mathrm{C}$ and $4{ }^{\circ} \mathrm{C}$, as predicted 
by the Arrhenius model (approximately, the maximum uptake rate and decay rate doubles with every $10^{\circ} \mathrm{C}$ increase) [29-31]. The higher metabolic rate at $37^{\circ} \mathrm{C}$ could have created a substrate scarcity, which could have resulted in a decline in methanogenic archaea abundance. Hagen et al. [14] reported that the relative abundance of most methanogens was particularly sensitive to storage temperature $(-20,4$ and $\left.20{ }^{\circ} \mathrm{C}\right)$. Specifically, Hagen et al. [14] reported that, in co-digestion, the fresh inoculum was dominated by hydrogenotrophic methanogens (e.g., Methanoculleus, Methanospirillum and Methanobrevibacter), which declined in favour of Methanosarcina during storage. However, the methanogenic population of the inoculum tested in the current study was characterised by a high abundance of Methanosaeta (acetoclastic methanogen) [2,25], and differences due to substrate affinity and decay rates may be expected. Although $4{ }^{\circ} \mathrm{C}$ appears to be the preferred temperature for short-term and long-term storage, the impact of (1) the amount of biodegradable organic matter in the inoculum, and (2) the inoculum's microbial composition and absolute abundance on the maximum storage time at different temperatures warrants further research.

\subsection{Implications}

Using the inoculum as fresh as possible stands as the preferred option for conducting metabolic activity assays and inhibition assays, being the only option that ensures that the inoculum truly represents the system under study. If the inoculum cannot be used directly after collection, storage at $4{ }^{\circ} \mathrm{C}$ is preferred, as discussed above. However, based on the present results and previous studies, an inoculum should be stored for as short as possible and should not be stored for more than a month, even at $4{ }^{\circ} \mathrm{C}$. Preferably, storage should be less than 2 weeks (see Section 3.2 and Figure 1). Experimental results from this study also suggest that inoculum pre-incubation at the test temperature is not important (see Section 3.1).

Storing the inoculum at room temperature $\left(20-22^{\circ} \mathrm{C}\right)$ is an attractive option when large volumes of inoculum need to be collected, or when there is limited refrigerator space. Based on the current results, this may be acceptable for short storage times, because the loss of activity is slightly faster than with storage at $4{ }^{\circ} \mathrm{C}$ (see Section 3.2). Additionally, these results imply that inoculum transportation could be possible at room temperature $\left(<25^{\circ} \mathrm{C}\right)$ over short periods of a few days, which is expected to be cheaper than refrigerated or cold shipment. However, in warm climates, it would be advisable to keep the inoculum as cold as possible during shipment. In contrast, freezing the inoculum is not recommended under any circumstances $[13,14]$.

Pre-incubating the inoculum at the test temperature prior to BMP testing (also known as degassing) is a common practice in the anaerobic digestion field to reduce inoculum methane production $[3,4,16,32]$. Inoculum pre-incubation aims to reduce the background contribution of the inoculum to the total methane production (inoculum + substrate), which has been postulated to improve BMP test precision [3,4,16]. In most publications, the inoculum is pre-incubated between 1 and 7 days prior to BMP testing [15-17]. However, our experimental results have shown that 7 days pre-incubation at $37^{\circ} \mathrm{C}$ could cause a noticeable decrease in inoculum methanogenic activity (see Sections 3.1 and 3.2). Indeed, Wang et al. [18] and Koch et al. [12] reported that storing the inoculum in mesophilic conditions $\left(35-38^{\circ} \mathrm{C}\right.$ ) for 5 and 14 days, respectively, had a negative impact on BMP test results. However, it should be noted that all these results have been obtained using digestate from a mesophilic digester treating municipal mixed sewage sludge as the inoculum. These digesters are typically operated conservatively (i.e., large hydraulic retention time and low organic loading rate) and, therefore, the inoculum is expected to have a low endogenous methane production and limited capacity to sustain the original microbial abundance and activity during lengthy storage. Using the inoculum as fresh as possible stands as the preferred option for BMP tests utilising the digestate of a mesophilic digester treating sewage sludge as the inoculum. This is particularly important because digested sewage was the inoculum recommended by Raposo et al. [16] and Holliger et al. [4] for BMP when a fully adapted inoculum is not available. However, as stated by Holliger et al. [4], the need to pre-incubate the inoculum as well as the pre-incubation time may depend on the amount of 
background biodegradable organic matter in the inoculum. Nonetheless, the selection of the inoculum pre-incubation duration should consider both the inoculum background methane production and inoculum activity.

\section{Conclusions}

This work clarified the impact of storage temperature and storage time on the specific methanogenic activity of two distinct inocula. The results showed that the methanogenic activity decreased over time regardless of the storage conditions. However, the rate at which the methanogenic activity decreased depended on the storage temperature. Inoculum stored at $4{ }^{\circ} \mathrm{C}$ and room temperature $\left(22^{\circ} \mathrm{C}\right)$ maintained methanogenic activity close to that of fresh inoculum for up to 14 days of storage, while the inoculum stored at $37^{\circ} \mathrm{C}$ showed a significant decline in methanogenic activity even after 7 days of storage. From this study, it can be concluded that it is preferable to keep inoculum storage to a minimum and, when needed, to store the inoculum at $4{ }^{\circ} \mathrm{C}$.

Supplementary Materials: The following are available online at http://www.mdpi.com/2073-4441/12/5/1321/s1, Figure S1: Experimental and regression model representing the evolution of methanogenic activity at $4{ }^{\circ} \mathrm{C}, 22^{\circ} \mathrm{C}$ and $37^{\circ} \mathrm{C}$; Table S1: Impact of storage temperature and time on DSS specific methanogenic activity.

Author Contributions: Conceptualization, S.A., S.T. and M.P.; methodology, S.A. and M.P.; formal analysis, S.A., K.K., S.W., S.D.H., S.T. and M.P.; investigation, S.A. and M.P.; resources, S.A.; data curation, S.A., S.D.H., S.W. and M.P.; writing-original draft preparation, S.A. and M.P.; writing - review and editing, K.K., S.W., S.D.H., S.T.; visualization, S.A., K.K. and M.P.; supervision, S.A.; project administration, S.A.; funding acquisition, S.A. All authors have read and agreed to the published version of the manuscript.

Funding: Sergi Astals is grateful to the Spanish Ministry of Science, Innovation and Universities for his Ramon y Cajal fellowship (RYC-2017-22372) and the Australian Research Council for his DECRA fellowship (DE170100497).

Acknowledgments: Beatrice Keller-Lehmann and Nathan Clayton at the Advanced Water Management Centre analytical lab for their assistance with samples chemical analyses.

Conflicts of Interest: The authors declare no conflict of interest.

\section{References}

1. Soto, M.; Mendez, R.; Lema, J.M. Methanogenic and non-methanogenic activity tests: Theoretical basis and experimental set up. Water Res. 1993, 27, 1361-1376. [CrossRef]

2. Peces, M.; Astals, S.; Jensen, P.; Clarke, W. Deterministic mechanisms define the long-term anaerobic digestion microbiome and its functionality regardless of the initial microbial community. Water Res. 2018, 141, 366-376. [CrossRef] [PubMed]

3. Angelidaki, I.; Alves, M.; Bolzonella, D.; Borzacconi, L.; Campos, J.L.; Guwy, A.J.; Kalyuzhnyi, S.; Jenicek, P.; van Lier, J.B. Defining the biomethane potential (BMP) of solid organic wastes and energy crops: A proposed protocol for batch assays. Water Sci. Technol. 2009, 59, 927-934. [CrossRef] [PubMed]

4. Holliger, C.; Alves, M.; Andrade, D.; Angelidaki, I.; Astals, S.; Baier, U.; Bougrier, C.; Buffière, P.; Carballa, M.; de Wilde, V.; et al. Towards a standardization of biomethane potential tests. Water Sci. Technol. 2016, 74, 2515-2522. [CrossRef] [PubMed]

5. Da Silva, C.; Astals, S.; Peces, M.; Campos, J.L.; Guerrero, L. Biochemical methane potential (BMP) tests: Reducing test time by early parameter estimation. Waste Manag. 2018, 71, 19-24. [CrossRef] [PubMed]

6. Koch, K.; Hafner, S.D.; Weinrich, S.; Astals, S.; Holliger, C. Power and Limitations of Biochemical Methane Potential (BMP) Tests. Front. Energy Res. 2020, 8. [CrossRef]

7. Lindorfer, H.; Pérez López, C.; Resch, C.; Braun, R.; Kirchmayr, R. The impact of increasing energy crop addition on process performance and residual methane potential in anaerobic digestion. Water Sci. Technol. 2007, 56, 55-63. [CrossRef]

8. Ruile, S.; Schmitz, S.; Mönch-Tegeder, M.; Oechsner, H. Degradation efficiency of agricultural biogas plants-A full-scale study. Bioresour. Technol. 2015, 178, 341-349. [CrossRef]

9. Owen, W.F.; Stuckey, D.C.; Healy, J.B.; Young, L.Y.; McCarty, P.L. Bioassay for monitoring biochemical methane potential and anaerobic toxicity. Water Res. 1979, 13, 485-492. [CrossRef] 
10. Astals, S.; Batstone, D.J.; Tait, S.; Jensen, P.D. Development and validation of a rapid test for anaerobic inhibition and toxicity. Water Res. 2015, 81, 208-215. [CrossRef]

11. Elbeshbishy, E.; Nakhla, G.; Hafez, H. Biochemical methane potential (BMP) of food waste and primary sludge: Influence of inoculum pre-incubation and inoculum source. Bioresour. Technol. 2012, 110, 18-25. [CrossRef] [PubMed]

12. Koch, K.; Hafner, S.D.; Weinrich, S.; Astals, S. Identification of critical problems in biochemical methane potential (BMP) tests from methane production curves. Fron. Environ. Sci. 2019, 7, 178. [CrossRef]

13. Castro, H.; Queirolo, M.; Quevedo, M.; Muxi, L. Preservation methods for the storage of anaerobic sludges. Biotechnol. Lett. 2002, 24, 329-333. [CrossRef]

14. Hagen, L.H.; Vivekanand, V.; Pope, P.B.; Eijsink, V.G.; Horn, S.J. The effect of storage conditions on microbial community composition and biomethane potential in a biogas starter culture. Appl. Microbiol. Biotechnol. 2015, 99, 5749-5761. [CrossRef] [PubMed]

15. Filer, J.; Ding, H.H.; Chang, S. Biochemical methane potential (BMP) assay method for anaerobic digestion research. Water 2019, 11, 921. [CrossRef]

16. Raposo, F.; De La Rubia, M.A.; Fernández-Cegrí, V.; Borja, R. Anaerobic digestion of solid organic substrates in batch mode: An overview relating to methane yields and experimental procedures. Renew. Sustain. Energy Rev. 2012, 16, 861-877. [CrossRef]

17. Ohemeng-Ntiamoah, J.; Datta, T. Perspectives on variabilities in biomethane potential test parameters and outcomes: A review of studies published between 2007 and 2018. Sci. Total Environ. 2019, 664, 1052-1062. [CrossRef]

18. Wang, B.; Strömberg, S.; Nges, I.A.; Nistor, M.; Liu, J. Impacts of inoculum pre-treatments on enzyme activity and biochemical methane potential. J. Biosci. Bioeng. 2016, 121, 557-560. [CrossRef]

19. Li, J.; Zicari, S.M.; Cui, Z.; Zhang, R. Processing anaerobic sludge for extended storage as anaerobic digester inoculum. Bioresour. Technol. 2014, 166, 201-210. [CrossRef]

20. Chen, Y.; Cheng, J.J.; Creamer, K.S. Inhibition of anaerobic digestion process: A review. Bioresour. Technol. 2008, 99, 4044-4064. [CrossRef]

21. Chen, J.L.; Ortiz, R.; Steele, T.W.J.; Stuckey, D.C. Toxicants inhibiting anaerobic digestion: A review. Biotechnol. Adv. 2014, 32, 1523-1534. [CrossRef]

22. Rice, E.W.; Baird, R.B.; Eaton, A.D.; Clesceri, L.S. Standard Methods for the Examination of Water and Wastewater; American Public Health Association: Washington, DC, USA, 2012.

23. Hafner, S.D.; Astals, S.; Buffiere, P.; Løjborg, N.; Holliger, C.; Koch, K.; Weinrich, S. Calculation of Methane Production from Manometric Measurements. Standard BMP Methods document 202, version 2.5. Available online: https://www.dbfz.de/en/BMP (accessed on 19 April 2020).

24. Hafner, S.D.; Koch, K.; Carrere, H.; Astals, S.; Weinrich, S.; Rennuit, C. Software for biogas research: Tools for measurement and prediction of methane production. SoftwareX 2018, 7, 205-210. [CrossRef]

25. Lu, Y.; Liaquat, R.; Astals, S.; Jensen, P.; Batstone, D.; Tait, S. Relationship between microbial community, operational factors and ammonia inhibition resilience in anaerobic digesters at low and moderate ammonia background concentrations. New Biotechnol. 2018, 44, 23-30. [CrossRef] [PubMed]

26. Regueiro, L.; Veiga, P.; Figueroa, M.; Alonso-Gutierrez, J.; Stams, A.J.; Lema, J.M.; Carballa, M. Relationship between microbial activity and microbial community structure in six full-scale anaerobic digesters. Microbiol. Res. 2012, 167, 581-589. [CrossRef] [PubMed]

27. Yamazawa, A.; Iikura, T.; Morioka, Y.; Shino, A.; Ogata, Y.; Date, Y.; Kikuchi, J. Cellulose Digestion and Metabolism Induced Biocatalytic Transitions in Anaerobic Microbial Ecosystems. Metabolites 2013, 4, 36-52. [CrossRef] [PubMed]

28. Sun, L.; Liu, T.; Müller, B.; Schnürer, A. The microbial community structure in industrial biogas plants influences the degradation rate of straw and cellulose in batch tests. Biotechnol. Biofuels 2016, 9, 128. [CrossRef]

29. Batstone, D.J.; Keller, J.; Angelidaki, I.; Kalyuzhnyi, S.V.; Pavlostathis, S.G.; Rozzi, A.; Sanders, W.T.; Siegrist, H.; Vavilin, V.A. The IWA Anaerobic Digestion Model No 1 (ADM1). Water Sci. Technol. 2002, 45, 65-73. [CrossRef]

30. Pavlostathis, S.G.; Giraldo-Gomez, E. Kinetics of anaerobic treatment: A critical review. Crit. Rev. Environ. Control. 1991, 21, 411-490. [CrossRef] 
31. Strübing, D.; Moeller, A.B.; Mößnang, B.; Lebuhn, M.; Drewes, J.E.; Koch, K. Anaerobic thermophilic trickle bed reactor as a promising technology for flexible and demand-oriented $\mathrm{H}_{2} / \mathrm{CO}_{2}$ biomethanation. Appl. Energy 2018, 232, 543-554. [CrossRef]

32. Hülsemann, B.; Zhou, L.; Merkle, W.; Hassa, J.; Müller, J.; Oechsner, H. Biomethane Potential Test: Influence of Inoculum and the Digestion System. Appl. Sci. 2020, 10, 2589. [CrossRef]

(C) 2020 by the authors. Licensee MDPI, Basel, Switzerland. This article is an open access article distributed under the terms and conditions of the Creative Commons Attribution (CC BY) license (http://creativecommons.org/licenses/by/4.0/). 